Personalidade Acadêmica Homenageada:

Raymundo Juliano Feitosa (Universidade Federal do Rio Grande do Norte - UFRN)

\title{
REFÉNS DO PODER: GESTÃO DOS DIREITOS HUMANOS DOS CIDADÃOS PERIFÉRICOS E O PAPEL DO ESTADO NA REALIDADE DO TRÁFICO DE DROGAS
}

\section{LUNNA LUIZA OLIVEIRA PETTERSEN}

Graduanda do curso de direito. Modalidade integral - Escola Superior Dom Helder Câmara - ESDHC. Belo Horizonte-MG . lunna.petter@gmail.com

CAIO AUGUSTO SOUZA LARA Mestre e Doutor em Direito pela Faculdade de Direito da Universidade Federal de Minas Gerais - UFMG. Professor da Escola Superior Dom Helder Câmara. Pesquisador associado ao Programa RECAJ-UFMG - Acesso à Justiça e Solução de Conflitos. Secretário de Comunicação do Conselho Nacional de Pesquisa e Pósgraduação em Direito - CONPEDI. Belo Horizonte-MG. E-mail: caiolarabh@yahoo.com.br.

\section{RESUMO}

O tema da presente pesquisa se volta ao controle dos direitos básicos dos moradores periféricos pela supremacia do controle dos traficantes de drogas e a precariedade da população que vive entre o embate de milícias e agentes do Estado. Efetivar os direitos fundamentais dos cidadãos é um dos maiores desafios enfrentados pelo estado, apesar de ser uma responsabilidade dele. Enfrenta-se ultimamente grandes impasses para que as pessoas tenham garantido condições dignas de vida, as preocupando com elementos que deveriam ser assegurados por direito. Quando essa situação é potencializada e a omissão dos órgãos estatais se torna mais grave, surgem brechas e irregularidades que propiciam a proliferação da ação do crime organizado. Essas facções criminosas possuem um sistema próprio, praticam 
Personalidade Acadêmica Homenageada:

Raymundo Juliano Feitosa (Universidade Federal do Rio Grande do Norte - UFRN)

atividades ilícitas e clandestinas, utilizando a violência e a intimidação para dominar certo território, assim, se tornam soberanos de um estado paralelo ao estado nacional.

Existem várias fontes que garantem a existência do crime organizado, mas a principal delas é o tráfico de drogas, que sustenta a dominação territorial e a soberania dos envolvidos. Em suma, os moradores de favela não têm em quem confiar, não têm um estado ou qualquer outra autoridade que os defenda. Estão sozinhos e precisam aprender a viver no meio do fogo cruzado, entre a máquina de guerra da polícia do Estado e o poder das armas dos comandos do tráfico. O problema objeto da investigação científica proposta é: quais os impactos socio-jurídicos para a população das favelas pelo conflito entre estado e o tráfico de drogas no domínio de poder e garantia de direitos fundamentais? A partir das reflexões preliminares sobre o tema, é possível afirmar que nas favelas da sociedade brasileira contemporânea existe o controle privado da segurança, propriedade e de serviços que normativamente deveriam ser estatais e públicos. Assim como existe um engano na imagem "heroica" do Estado, sendo que ele não consegue cumprir sua função de "dar a todos o que é de direito" potencializando o crime organizado. Portanto, constata-se a premência de moderação e descentralização nessa gestão do tráfico e do estado, para que não restrinja o poder de escolha desses moradores, garantindo-os o direito de discernir o que é melhor, sem estar sob a manipulação do medo das sanções aplicadas pelos criminosos e pela opressão estatal. O objetivo geral do trabalho é analisar a estrutura jurídica-social das periferias e comprovar a existência da dualidade estado-facções, que se conflitam com a garantia dos direitos fundamentais aos seus moradores e sua relação de submissão. A pesquisa que se propõe pertence à vertente metodológica jurídico-sociológica. No tocante ao tipo de investigação, foi escolhido, na classificação de Witker (1985) e Gustin (2010), o tipo jurídico-projetivo. O raciocínio desenvolvido na pesquisa será predominantemente dialético. De acordo com a técnica de análise de conteúdo, afirma-se que se trata de uma pesquisa teórica, o que será possível a partir da análise de conteúdo dos textos doutrinários, normas e demais dados colhidos na pesquisa. Conclui-se que o combate em caráter mais estratégico do crime organizado está aliado à defesa de um maior protagonismo do Estado oficial. Principalmente nas suas organizações que tem como finalidade combater o crime. A 
Personalidade Acadêmica Homenageada:

Raymundo Juliano Feitosa (Universidade Federal do Rio Grande do Norte - UFRN)

inteligência como característica da ação pública é primordial para minimizar as ações do crime organizado e se mostrou muito eficaz em algumas operações. Contudo, também se faz necessário o surgimento de novos atores nacionais (terceiro setor) e a efetivação dos que já existem no plano internacional, como as normas da ONU, para que a democratização do sistema de proteção dos direitos humanos se concretize. Não é mais admissível que Estados proclamem os direitos da população periférica, mas lhes neguem a efetivação.

PALAVRAS-CHAVES: Direitos humanos; Direitos Fundamentais; Estado; Poder Paralelo.

\section{REFERÊNCIAS}

ALVES, Maria Helena Moreira; EVANSON, Philip. Vivendo no fogo cruzado: moradores de favela, traficantes de drogas e violência policial no Rio de Janeiro. Rio de Janeiro: unesp, 2013.

BOBBIO, Norberto. Era dos direitos. 7ª . ed. Rio de Janeiro: Elsevier, 2004.

BRASIL. [Constituição (1988)]. Constituição da República Federativa do Brasil. 53a․ ed. Brasília; Câmara, 2018.

Código penal. Organizado por Aloysio de Brito Vieira. Brasília: Senado $\overline{\text { Federal, }}$ Coordenação de Edições Técnicas, 2017. (Legislação brasileira).

. Lei Antidroga, Lei no 11.343, de 23 de agosto de 2006. Organizado por Paulo Roberto Moraes de Aguiar. $2^{\mathrm{a}}$. ed. Brasília: Senado Federal, Subsecretaria de Edições Técnicas, 2012.

GUSTIN, Miracy Barbosa de Sousa; DIAS, Maria Tereza Fonseca. $(\mathbf{R e})$ pensando a pesquisa jurídica: teoria e prática. 3ª . ed. Belo Horizonte: Del Rey, 2010.

MANSO, Bruno Paes; DIAS, Camila Nunes. A guerra: a ascensão do pcc e o mundo do crime no Brasil. São Paulo: Todavia, 2018.

MIKALOVSKI, Algacir. Os impactos das ações afirmativas na segurança pública. ISSN: 2316-753X. Revista jurídica - Unicuritiba. V. 1, N. 54 (2019): janeiro - março. Disponível em: http://revista.unicuritiba.edu.br/index.php/RevJur/article/download/208/181 . 
Personalidade Acadêmica Homenageada:

Raymundo Juliano Feitosa (Universidade Federal do Rio Grande do Norte - UFRN)

Acesso em: 22 de maio de 2019.

O QUE SÃO os direitos humanos? Portal: Nações Unidas Brasil. 2017. Disponível em: https://nacoesunidas.org/direitoshumanos/documentos/. Acesso em: 11 de maio de 2019.

WITKER, Jorge. Como elaborar uma tesis en derecho: pautas metodológicas y técnicas para el estudiante o investigador del derecho. Madrid: Civitas, 1985. 